\title{
Demonstration of an Office Powered by Solar PV System
}

\author{
Bin-Juine Huang, Po-Chien Hsu, Y.H. Wang, J.H. Tsai, Leo Chen, Kang Li, KY Lee \\ Department of Mechanical Engineering, National Taiwan University, Taipei, Taiwan.
}

\begin{abstract}
The purpose of the present study is to demonstrate the concept of peak-suppression by energy saving and solar PV energy supply to replace nuclear power. An office with $150 \mathrm{~m}^{2}$ floor area and 15 employees was chosen as the demonstration site. The results show that retrofit for energy-saving reduces $65 \%$ energy and the solar PV system supplies $20 \%$. The total energy reduction is $85 \%$. The measured average total power consumption of the office is reduced from $10.2 \mathrm{~kW}$ to $3.6 \mathrm{~kW}$ (after retrofit) in which solar PV supplies about half. The total initial investment of the solar PV system and the retrofit of energy-saving equipment is around USD30,000. The net total energy saving in 20 years is USD 80,000. The system has been run about one year.
\end{abstract}

Keywords: solar PV energy, distributed solar system, solar energy office

\section{Introduction}

Grid power demand during peak load is caused mainly by energy consumption of air conditioning systems. Solar PV system is the best solution for peak-shaving. In addition, the utilization of solar PV power system should be for self-consumption, rather than feeding back to grid and causing transmission problem when solar PV is in high-level of penetration. That is, solar PV distributed system will be one of the future major energy supplies in the world.

Since Taiwan is located in subtropical area, the highest peak load during summer is around 34GW. From a long-term study, the power consumption of air conditoning contributes about $9 \mathrm{GW}$, almost twice of the installed capacity of nuclear power 5.1GW. Energy saving of air conditioning is thus most important.

Taiwan Government has set up an energy-efficiency classification for air conditioners since 2010. Five categories are defined according to the energy efficiency ratio (EER) (W/W) and cooling capacity. See Table 1. However, EER of majority of air conditioners in the market or ever installed is below 3.5 (Category 3 5). In 2010, $70 \%$ of air conditoners belongs to Category 5. Large potential of energy saving is feasible since the EER of the most advanced air conditioner in the market is higher than 5.6.

Table 1: Category of air conditioners

\begin{tabular}{|c|c|c|c|c|c|c|}
\hline \multirow[t]{2}{*}{ Type } & \multirow{2}{*}{$\begin{array}{l}\text { Cooling capacity, } \\
\text { kW } \\
\text { Category }\end{array}$} & \multicolumn{5}{|c|}{ EER (W/W) } \\
\hline & & 1 & 2 & 3 & 4 & 5 \\
\hline Integral-type & $\begin{array}{c}<2.2 \\
2.2 \sim 4.0 \\
4.0 \sim 7.1 \\
7.1 \sim 10\end{array}$ & $>3.4$ & $3.25 \sim 3.4$ & $3.1 \sim 3.25$ & $2.95 \sim 3.1$ & $<2.95$ \\
\hline Split-type & $\begin{array}{c}<4.0 \\
4.0 \sim 7.1 \\
>7.1\end{array}$ & $\begin{array}{l}>4.17 \\
>3.87 \\
>3.81\end{array}$ & $\begin{array}{l}3.93 \sim 4.17 \\
3.65 \sim 3.87 \\
3.59 \sim 3.81\end{array}$ & $\begin{array}{l}3.69 \sim 3.93 \\
3.42 \sim 3.65 \\
3.37 \sim 3.59\end{array}$ & $\begin{array}{c}3.45 \sim 3.69 \\
3.2 \sim 3.42 \\
3.15 \sim 3.37\end{array}$ & $\begin{array}{l}<3.45 \\
<3.20 \\
<3.15\end{array}$ \\
\hline
\end{tabular}

Besides, lighting consumes about 10 15\% energy in Taiwan. It is known that LED (light-emitting-diode) can save more than $50 \%$ lighting energy. Thus, lighting energy saving using LED is also feasible. 
The cost of solar PV energy is reduced dramatically recently to bring the grid-parity age to come. Today, energy from solar PV is equal or cheaper than from the grid. High-efficiency air conditioning, LED lighting, and low-cost solar PV are all technically mature and available in the market.

The purpose of the present study is to demonstrate the concept of peak-suppression by energy saving first and then replacement of peak load by solar PV energy supply. This may be able to completely abandon nuclear power in Taiwan, as shown in Fig.1. An office in a 7-floor building located in Taipei with $150 \mathrm{~m}^{2}$ floor area and 15 employees was chosen as the demonstration site.

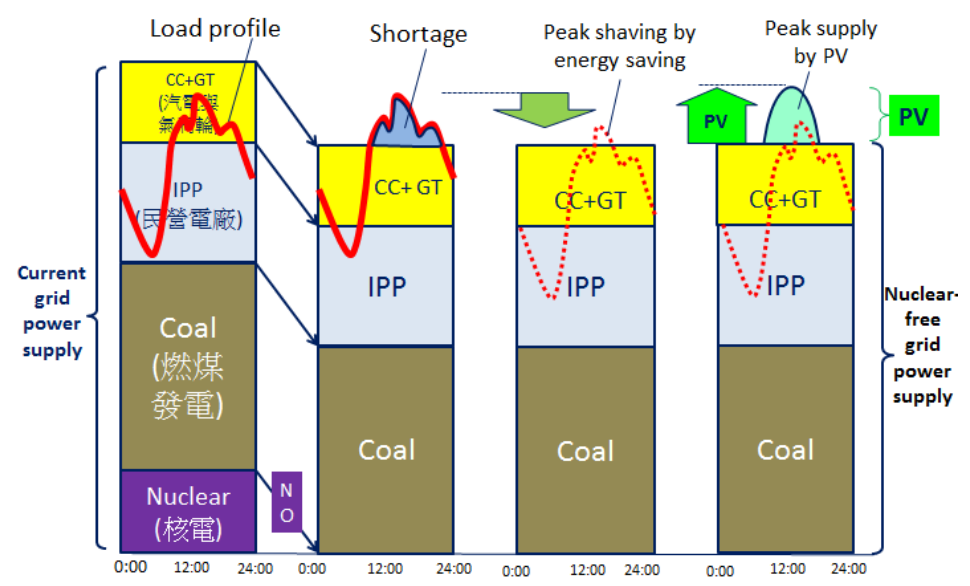

Fig. 1: The concept of nuclear power abandon by energy saving and using solar PV energy.

\section{Retrofit of energy equipment and solar PV supply}

\subsection{Retrofit for energy saving}

\section{Energy consumption before energy-saving retrofit}

The office of the Department of Mechanical Engineering, National Taiwan University, with $150 \mathrm{~m}^{2}$ floor area and occupied by 15 employees, was chosen as the demonstration site (D-1). The major energy consumption of the office comes from air conditoning, lighting, and PC. The power and daily energy consumption of air conditioners, lighting, and laptop PC was analyzed and listed in Table 2. It is seen that the total power consumption for air conditioners, lighting, and PC reaches $10.16 \mathrm{~kW}$ and the daily total energy consumption reaches $81.3 \mathrm{kWh} .64 \%$ energy is consumed by air conditioners.

Table 2: Energy consumption before retrofit.

\begin{tabular}{|c|c|c|}
\hline Daily consumption @8 h/day & $\begin{array}{c}\text { Power input, } \\
\mathrm{kW}\end{array}$ & $\begin{array}{l}\text { Daily energy, } \\
\text { kWh/day }\end{array}$ \\
\hline \multicolumn{3}{|l|}{ (1)Air conditioning } \\
\hline \multicolumn{3}{|l|}{ Room 1: One split-type MW3299 BFR: cooling } \\
\hline $\begin{array}{l}\text { One window-type : cooling } 5.8 \mathrm{~kW} \text {, } \\
\text { COP } 2.9\end{array}$ & 2 & 16 \\
\hline $\begin{array}{l}\text { Room 2: One window-type MW550BR: cooling } \\
5.8 \mathrm{~kW}, \text { COP } 2.9\end{array}$ & 2 & 16 \\
\hline Energy consumption & 6.5 & 52 \\
\hline \multicolumn{3}{|l|}{ (2)Lighting } \\
\hline Room 1: Recessed fluorescent $(47 \mathrm{~W}) 26$ sets & 1.222 & 9.8 \\
\hline Room 2: Recessed fluorescent $(47 \mathrm{~W}) 4$ sets & 0.188 & 1.5 \\
\hline Energy consumption & $\begin{array}{c}0.100 \\
1.41\end{array}$ & 11.3 \\
\hline \multicolumn{3}{|l|}{ (3) $\mathrm{PC}$} \\
\hline 13 laptop PC, $150 \mathrm{~W}$ each & 1.95 & 15.6 \\
\hline 2 laptop PC, $150 \mathrm{~W}$ each & 0.3 & 2.4 \\
\hline Energy consumption & 2.25 & 18 \\
\hline $\begin{array}{l}\text { Total energy consumption } \\
\text { (air conditioners, lighting, PC) }\end{array}$ & 10.16 & 81.3 \\
\hline
\end{tabular}




\section{Energy-saving retrofit and energy consumption}

To reduce energy consumption, four retrofitting was carried out: (1)air conditioning system is renewed with high-efficiency split-type air conditioner (Hitachi RAC-22NB) with COP 5.6; (2)lighting is retrofitted with LED luminaire with $100 \mathrm{Lm} / \mathrm{W}$; (3)all lap-top computers are changed into notebook PC; (4)the window glass is covered with low-E film to block IR part of solar radiation penetrating into the office. The above four retrofits results in 65\% energy saving as shown in Table 3, at an average $3.6 \mathrm{~kW}$ (from $10.2 \mathrm{~kW}$ ) and daily energy consumption $28.6 \mathrm{kWh} /$ day (from $81.3 \mathrm{kWh} /$ day).

Table 3: Energy consumption before retrofit.

\begin{tabular}{|c|c|c|c|c|c|c|}
\hline \multicolumn{3}{|c|}{ Before energy-saving retrofit } & \multicolumn{3}{|c|}{ After energy-saving retrofit } & \multirow[t]{2}{*}{$\begin{array}{l}\text { Energy } \\
\text { saving }\end{array}$} \\
\hline Old equipment & $\begin{array}{l}\text { Power } \\
\text { input, } \\
\mathrm{kW}\end{array}$ & $\begin{array}{c}\text { Daily } \\
\text { energy, } \\
\text { kWh/day }\end{array}$ & New equipment & $\begin{array}{l}\text { Power } \\
\text { input, } \\
\text { kW }\end{array}$ & $\begin{array}{l}\text { Daily } \\
\text { energy, } \\
\text { kWh/day }\end{array}$ & \\
\hline \multicolumn{7}{|l|}{ (1)Air conditioner } \\
\hline $\begin{array}{l}\text { Room 1: One split-type MW3299 } \\
\text { BFR: cooling } 7.3 \mathrm{~kW}, \\
\text { COP } 2.92\end{array}$ & 2.5 & 20 & $\begin{array}{l}\text { Five Hitachi split-type RAC } 22 \mathrm{NB} \text { : } \\
\text { cooling } 2.2 \mathrm{~kW} \text {, COP } 5.6\end{array}$ & 2 & 16 & $20 \%$ \\
\hline $\begin{array}{l}\text { One window-type : cooling } \\
5.8 \mathrm{~kW}, \text { COP } 2.9\end{array}$ & 2 & 16 & & & & \\
\hline \multirow{2}{*}{$\begin{array}{l}\text { Room 2: One window-type } \\
\text { MW550BR: cooling } 5.8 \mathrm{~kW} \text {, } \\
\text { COP } 2.9 \\
\text { Energy consumption }\end{array}$} & 2 & 16 & $\begin{array}{l}\text { One Hitachi split-type RAC22NB: } \\
\text { cooling } 2.2 \mathrm{~kW}, \text { COP } 5.6\end{array}$ & 0.4 & 3.2 & $80 \%$ \\
\hline & 6.5 & 52 & & 4.4 & 19.2 & $63 \%$ \\
\hline \multicolumn{7}{|l|}{ (2)Lighting } \\
\hline $\begin{array}{l}\text { Room 1: } \begin{array}{l}\text { Recessed T8 fluorescent } \\
(47 \mathrm{~W}) 26 \text { sets }\end{array}\end{array}$ & 1.222 & 9.8 & Recessed T8 LED (30W): 20 sets & 0.6 & 4.8 & $51 \%$ \\
\hline $\begin{array}{l}\text { Room 2: Recessed T8 fluorescent } \\
\text { (47W) } 4 \text { sets }\end{array}$ & 0.188 & 1.5 & Recessed T8 LED (30W): 4 sets & 0.12 & 0.96 & $36 \%$ \\
\hline Energy consumption & 1.41 & 11.3 & & 0.72 & 5.76 & $49 \%$ \\
\hline \multicolumn{7}{|l|}{ (3)PC } \\
\hline 13 laptop PC, $150 \mathrm{~W}$ each & 1.95 & 15.6 & $13 \mathrm{NB}, 30 \mathrm{~W}$ each & 0.39 & 3.12 & $80 \%$ \\
\hline Room 2: 2 laptop PC, $150 \mathrm{~W}$ each & 0.3 & 2.4 & $2 \mathrm{NB}, 30 \mathrm{~W}$ each & 0.06 & 0.48 & $80 \%$ \\
\hline Energy consumption & 2.25 & 18 & & 0.45 & 3.6 & $80 \%$ \\
\hline $\begin{array}{l}\text { Total energy consumption } \\
\text { (air conditioners, lighting, PC) }\end{array}$ & 10.16 & 81.3 & & 3.57 & 28.6 & $65 \%$ \\
\hline
\end{tabular}

\subsection{Solar PV system design}

A $6 \mathrm{kWp}$ hybrid solar PV system is installed to replace another $20 \%$ energy. That is, $85 \%$ energy consumption is reduced in total.

The solar PV system is an isolated-type hybrid solar PV system (HyPV) which operates in Stand-alone PV Mode or Grid Mode, automatically. Fig.2 No solar PV energy is fed back to grid. When solar power generation and battery storage is sufficient, it operates in Stand-alone PV Mode and the load is powered completely by solar energy. When solar power generation and battery storage is not sufficient, it will switch to Grid Mode and the load is supplied completely by grid. The intelligent controller (MCU) performs optimal switching control between Stand-alone PV Mode and Grid Mode to reduce cycling of battery and ATS. The microprocessor-based MCU also carries out solar charging and system protection control, etc.
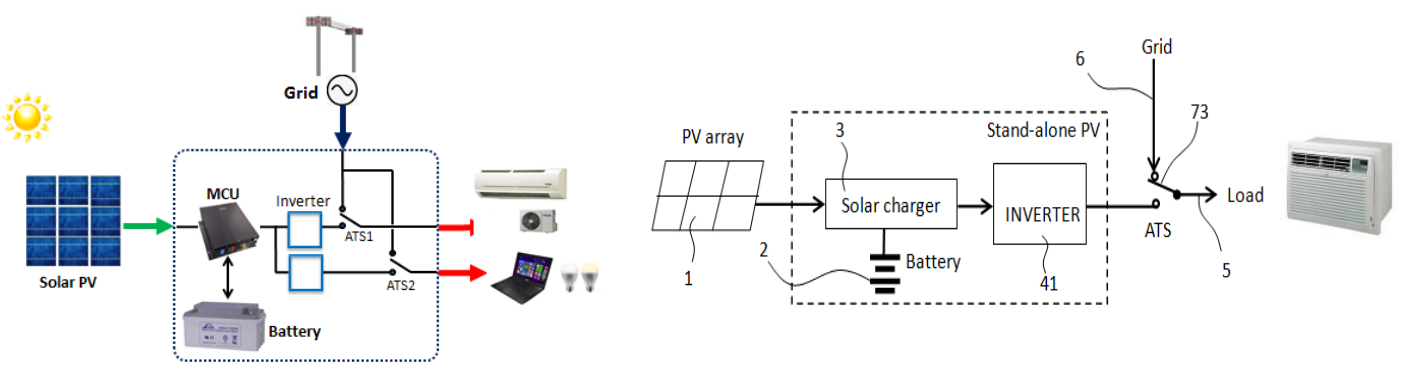

Fig. 2: Hybrid solar PV system (HyPV) 
The HyPV utilizes nMPPO (near maximum-power-point operation) system design (Huang et al, 2006) to eliminate the conventional MPPT (maximum-power-point tracking control) but still keep optimal performance. This reduces MPPT energy loss and hardware cost and increases the reliability. The HyPV also utilizes direct PV charging control technique for battery to avoid energy loss and malfunction of conventional charger. This reduces cost and increases reliability. Fig. 3 shows the installation of HyPV on roof-top for energy supply of the office.

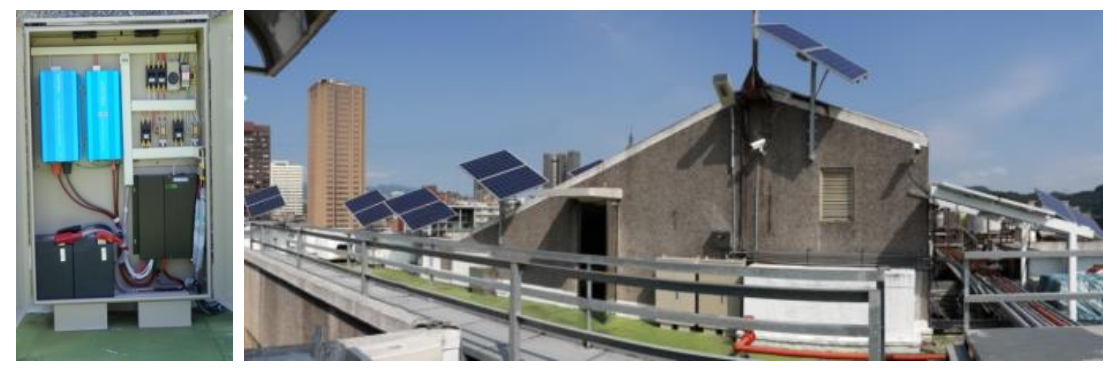

Fig. 3: Hybrid solar PV system for office energy supply.

The design of $5.88 \mathrm{kWp}$ solar PV system is shown in Table 4. To increase power generation, 1A-3P (oneaxis 3-position) sun tracker is used to mount PV panels. The energy generation will be increased by $25 \%$ in Taipei (Huang et al, 2007). The solar PV system is divided into two $2.94 \mathrm{kWp}$ subsystems. No.1 supplies 4 air conditioners (220VAC). No.2 supplies power to drive 2 air conditioners (220VAC) and LED lighting and PC's (110VAC) (Fig. 3). The installation is as shown in Fig. 4.

Table 4: PV system design.

\begin{tabular}{lc}
\hline Solar PV system: & \\
(1)energy generation capability, $\mathrm{kWh} / \mathrm{kWp}-\mathrm{yr}$ & 900 \\
(2)PV installed capacity, $\mathrm{kWp}$ & 5.88 \\
(3)system loss & $10 \%$ \\
(4)power enhancement by $1 \mathrm{~A}-3 \mathrm{P}$ & 1.25 \\
(5)average daily generation, $\mathrm{kWh} / \mathrm{day}$ & 16.31 \\
(6)highest daily generation, $\mathrm{kWh} / \mathrm{day}$ & 24.47 \\
(7)lowest daily generation, $\mathrm{kWh} / \mathrm{day}$ & 2.35 \\
(8)max load, $\mathrm{kWh} / \mathrm{day}$ & 28.6 \\
\hline Battery storage: & \\
(1) Li-battery capacity, $\mathrm{kWh}$ & 2.88 \\
(2) running time at full load, hr & 0.8 \\
(3) running time for $\mathrm{A} / \mathrm{C}, \mathrm{hr}$ & 1.2 \\
(4) running time for lighting, hr & 4.0 \\
\hline
\end{tabular}

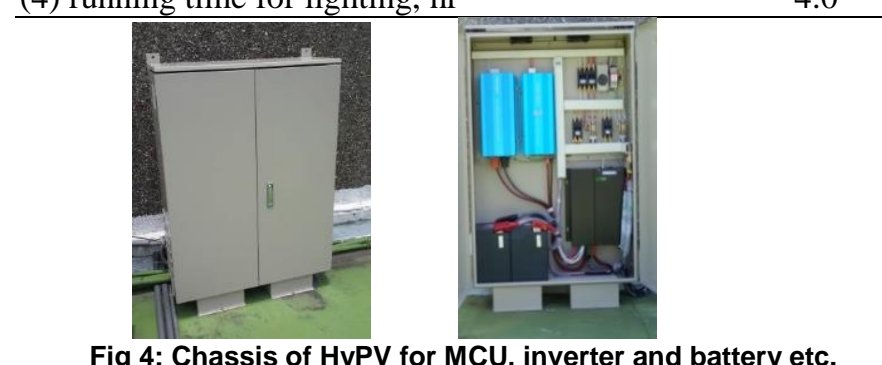

Fig 4: Chassis of HyPV for MCU, inverter and battery etc.

\section{Test results}

The installation of HyPV system including measuring system was completed in July 2014. The performance was monitored continuously from August, 2014. Fig. 5 shows the 5-month operation of No.1 unit which is used to supply 4 air conditioners. According to statistical data from the government monitoring network around Taiwan, the daily PV energy generation per unit PV installation is $2.47 \mathrm{kWh} / \mathrm{kWp}$ per day $(900 \mathrm{kWh} /$ $\mathrm{kWp}$-yr). Fig. 6 shows that the 5-month performance of No.1 is $2.17 \mathrm{kWh} / \mathrm{kWp}$ per day in average which is $12 \%$ lower than the statistical data. This is due to low load in fall season while air conditioner is not frequently used. 

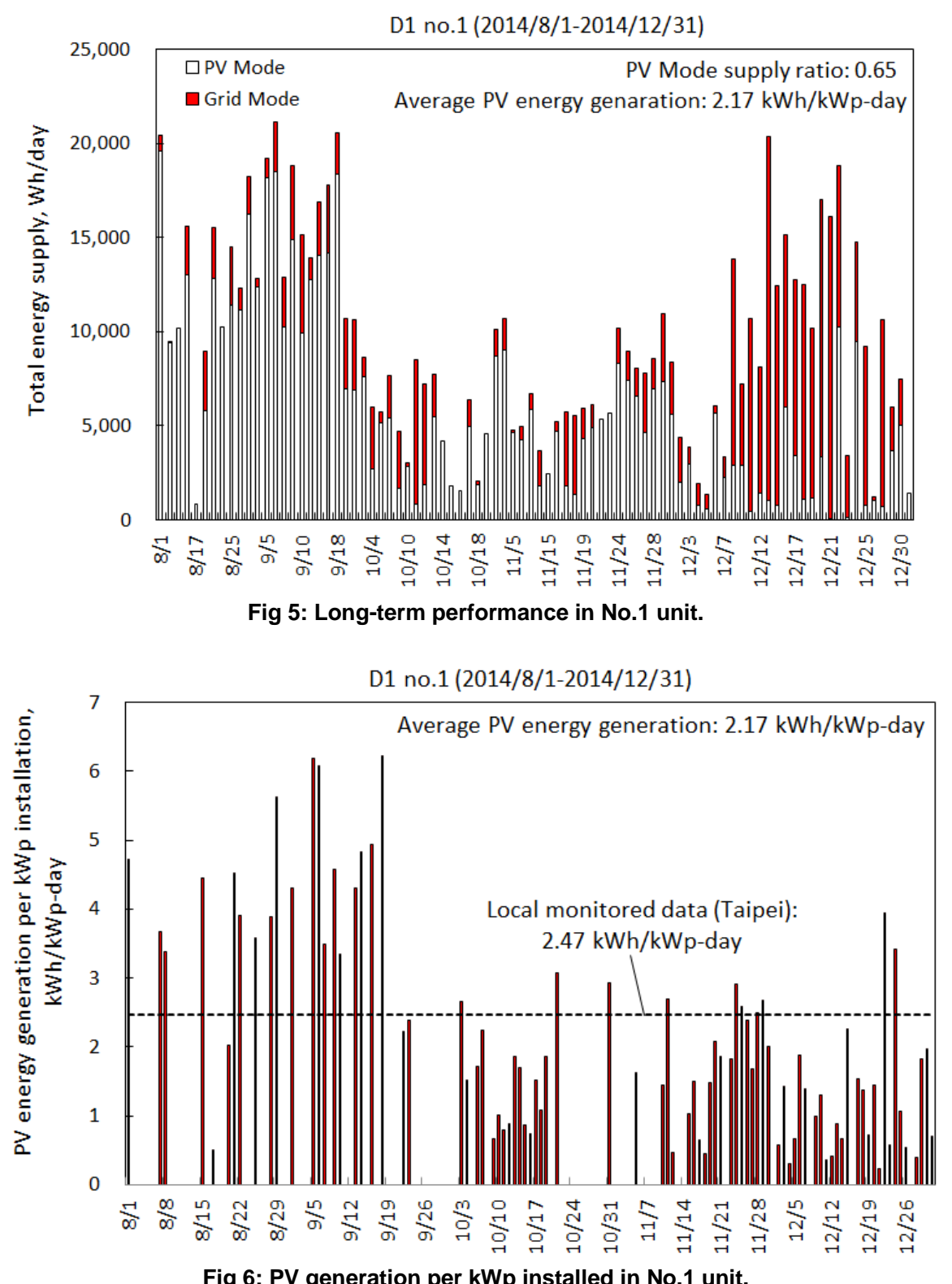

The daily total load or energy supply (PV-Mode and Grid-Mode) of No.2 unit is shown in Fig 7. It reaches $2.67 \mathrm{kWh} / \mathrm{kWp}$ per day, $8.1 \%$ higher than the statistical result. This is due to the fact that the load demand of LED lighting and NB supplied by No.2 unit is rather steady all year round.

Table 5 is the long-term results in PV energy generation and solar fraction. It shows that the PV energy generation per PV installed reaches $2.42 \mathrm{kWh} / \mathrm{kWp}$ per day (Fig.8), approaching the statistical result (2.47). This means that no PV energy generation loss for the whole D-1 system, even it is operated only in weekdays and at low load condition in fall season. 


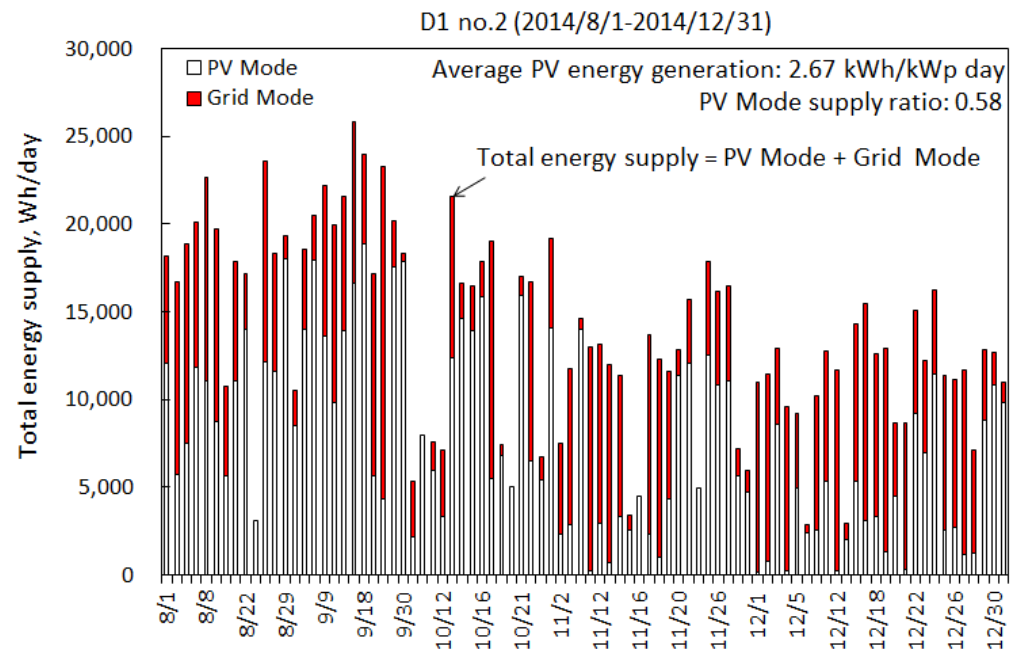

Fig 7: Long-term performance of No.2 unit.

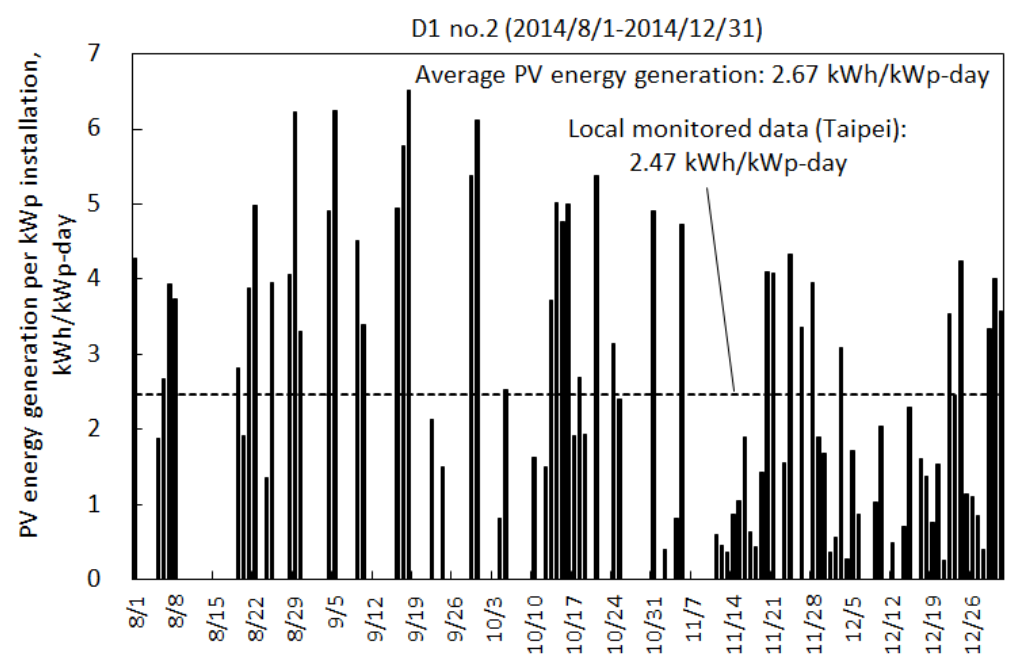

Fig 8: PV generation per kWp installed of No.2 unit.

Table 5: Performance of D-1 system in 2014.

\begin{tabular}{ccc|ccc|cc}
\hline & \multicolumn{2}{c|}{ No.1 } & \multicolumn{2}{c|}{ No.2 } & \multicolumn{2}{c}{ No.1+No.2 } \\
\cline { 2 - 4 } D-1 & $\begin{array}{c}\text { PV generation } \\
\text { per kWp } \\
\text { installation, } \\
\text { kWh/kWp-day }\end{array}$ & $\begin{array}{c}\text { Solar } \\
\text { fraction }\end{array}$ & $\begin{array}{c}\text { PV generation } \\
\text { per kWp } \\
\text { installation, } \\
\text { kWh/kWp-day }\end{array}$ & $\begin{array}{c}\text { Solar } \\
\text { fraction }\end{array}$ & $\begin{array}{c}\text { generation } \\
\text { loss, } \%\end{array}$ & $\begin{array}{c}\text { PV generation } \\
\text { per kWp } \\
\text { installation, } \\
\text { kWh/kWp-day }\end{array}$ & $\begin{array}{c}\text { Solar } \\
\text { fraction }\end{array}$ \\
\hline $2014 / 8$ & 3.71 & 0.88 & 3.5 & 0.61 & - & 3.61 & 0.745 \\
$2014 / 9$ & 4.4 & 0.87 & 4.67 & 0.68 & 8.6 & 4.54 & 0.775 \\
$2014 / 10$ & 1.59 & 0.75 & 3.7 & 0.7 & 52.7 & 2.65 & 0.725 \\
$2014 / 11$ & 1.77 & 0.73 & 2.15 & 0.48 & 17.7 & 1.96 & 0.605 \\
$2014 / 12$ & 1.21 & 0.29 & 1.95 & 0.4 & 33.3 & 1.58 & 0.345 \\
\hline Average & 2.17 & 0.65 & 2.67 & 0.58 & 18.8 & 2.42 & 0.615 \\
\hline
\end{tabular}

Fig 9 shows that the 7-month total energy supply (load) of D-1 in 2015 is lower than the estimation (28.6 $\mathrm{kWh} /$ day), except in summer. The PV-Mode supply ratio is 0.75 . The load demand in March is quite low which increases the PV generation loss. However, the PV energy generation reaches $20.94 \mathrm{kWh} /$ day in summer (June and July), 28\% higher than average prediction. Fig.10.

The design of D-1 system is based on the concept of PV energy for self-consumption and small battery storage to reduce cost. The battery is used as a buffer to stabilize the instantaneous load only. The long-term test results for a year shows that the PV energy generation loss is low. 

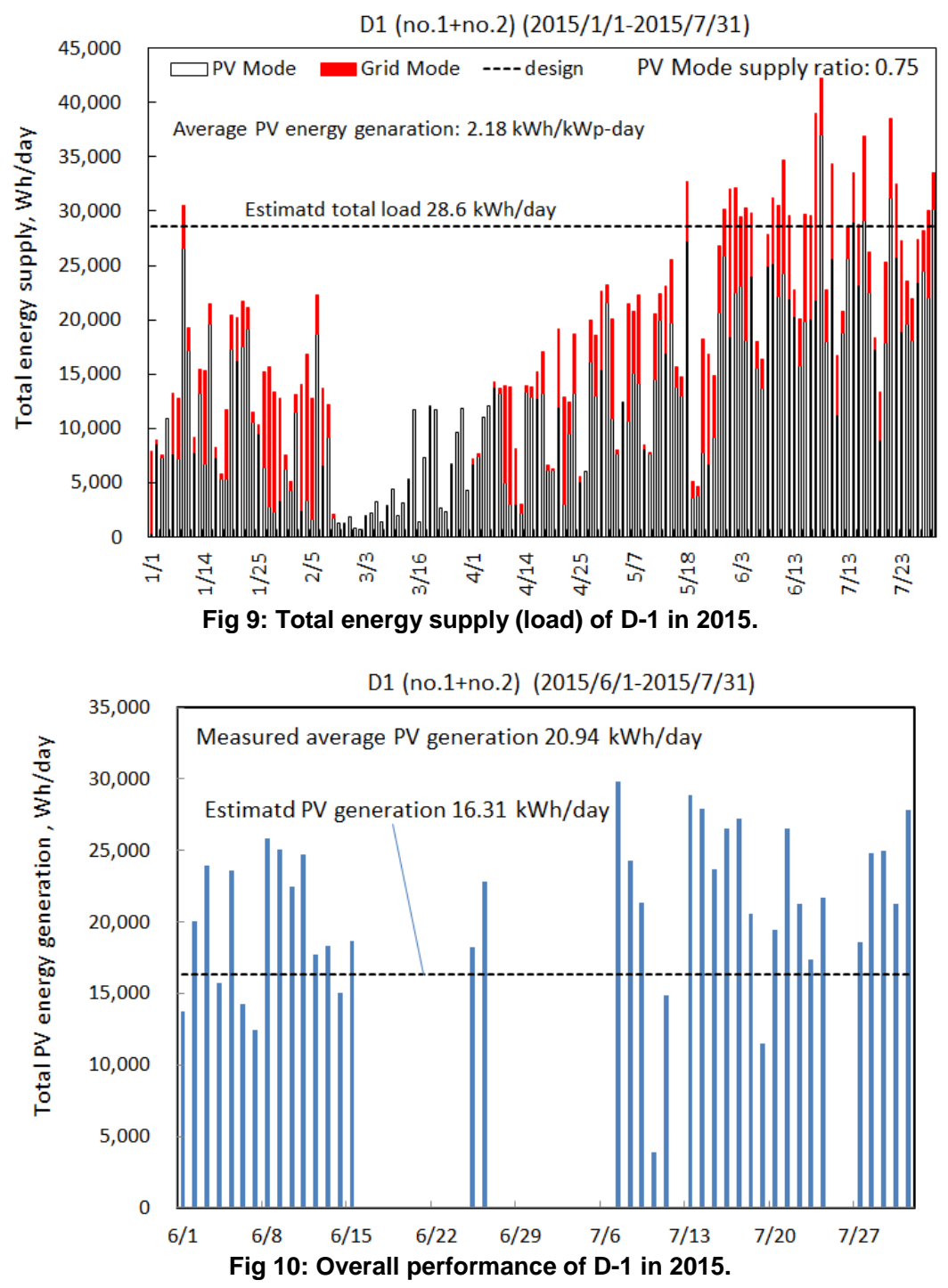

\section{Economic Feasibility}

The total investment of the solar PV system and the retrofit of air conditioning system, lighting devices, window insulation etc. is around USD30,000. The net total energy saving in 20 years is USD 80,000, including $\mathrm{M} \& \mathrm{O}$ cost. The system has been run about one year. The measured total power consumption of the office is reduced from $10.2 \mathrm{~kW}$ to $3.6 \mathrm{~kW}$ (after retrofit), about $65 \%$. The solar PV system supplies about half of the rest of energy demand of the office. That is, $85 \%$ energy reduction in total.

The economic analysis (Table 5) shows that the total energy saving through retrofit and PV installation reaches $85 \%$ in Taipei (poor solar area) and $96 \%$ in Tainan (rich solar area). This indicates that the present demonstration system (D-1) can approach zero-energy office if installed in a solar rich area. The payback time is $8 \mathrm{yr}$ in Taipei and $7.5 \mathrm{yr}$ in Tainan.

\section{Conclusions}

The present study shows that, performing energy saving retrofit then utilizing solar PV energy to supply the remaining load demand in grid can solve the energy shortage problem, if nuclear power was abandoned in Taiwan. An office located in Taipei with $150 \mathrm{~m}^{2}$ floor area and 14 employees was chosen as the demonstration site (D-1). Four energy-saving retrofitting on air conditioning, lighting, PC, and anti-IR film on window glass results in $65 \%$ energy saving. A $6 \mathrm{kWp}$ solar PV system is further installed to replace additional $20 \%$ energy. That is, $85 \%$ energy is saved in total. The solar PV system is an isolated-type hybrid 
solar PV system (HyPV) which operates under Stand-alone PV Mode or Grid Mode, automatically, by a power controller. No solar PV energy is fed back to grid. The total investment for the solar PV system and the retrofit for energy saving is around USD30,000. The net total energy saving in 20 years is USD80,000, including M\&O cost. System D-1 has been run more than one year. The solar PV system supplies about $60 \%$ final energy demand of the office.

If energy-saving in air conditioning and lighting can reach $60 \%$ as D-1 did in the whole country, the nuclear power $(18 \%)$ can be abandomed by using solar PV installation to supply the remaining load demand with proper energy storage.

Table 5: Economic analysis.

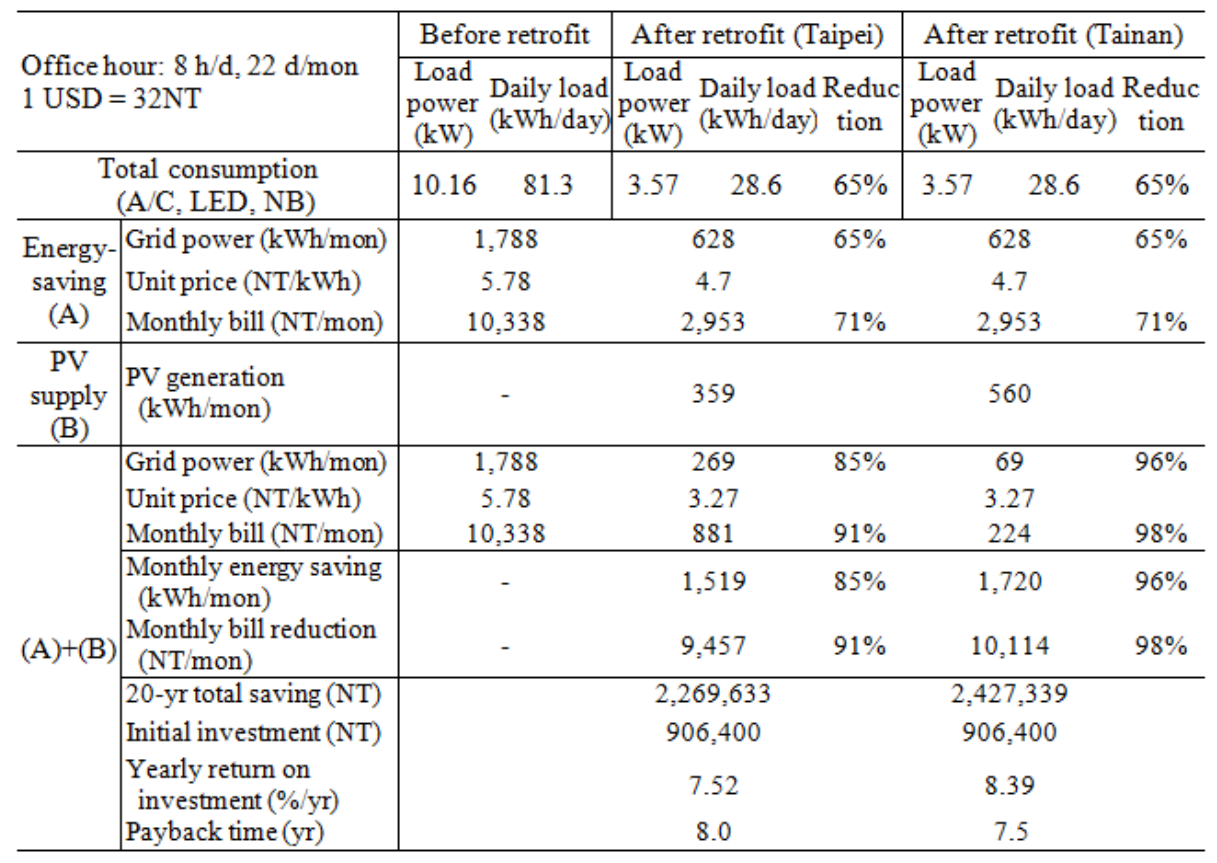

\section{Acknowledgement}

This study was supported by National Energy Program II, MOST 103-3113-E-002-006 made by Ministry of Science and Technology, Taiwan.

\section{References}

Huang, B.J., Sun, F.S., Ho. R.W. 2006. Near-maximum-power-point-operation (nMPPO) design of photovoltaic power generation system. Solar Energy 80, 1003-1020.

Huang, B.J. and Sun, F.S. 2007. Feasibility study of 1-axis three-position tracking solar PV with low concentration ratio reflector. Energy Conversion and Management 48, 1273-1280. 